\title{
1 \\ Basics of Clinical Metabolic Research
}

\author{
Michael Roden
}

Metabolic diseases, particularly obesity, dyslipidaemia and type 2 diabetes mellitus (T2DM), as well as conditions of increased risk for these diseases such as factors of the (dys)metabolic syndrome have become dramatically more prevalent over the last decade. Both in the industrialised world and, even more so, in developing regions and countries - which feature rapidly increasing economies and are adopting the so-called Western lifestyle - these diseases, particularly overweightness and obesity, are a growing health problem (Kopelman 2000). It is assumed that T2DM could be the largest epidemic in human history (Zimmet 2005) as more than 190 million people worldwide are diabetic and more than 300 million suffer from impaired glucose tolerance, the immediate pre-diabetic state. Recent calculations suggest that in the year 2025 more than 300 million people will have overt diabetes, mainly T2DM, with excessive growth in developing countries (King et al. 1998).

Diabetes mellitus is already the leading cause of blindness among working-age adults, of end-stage renal disease and of non-traumatic loss of limb (Ullbrecht et al. 2004; Williamson et al. 2004). The global mortality attributable to diabetes in the year 2000 was estimated to be 2.9 million deaths, which was $5.2 \%$ of all death. Thus diabetes is the fifth leading cause of death globally. About $2-3 \%$ of the population in low-economy countries and up to $8 \%$ in the United States and Canada die because of diabetes (Roglic et al. 2005). The costs caused by diabetes are enormous.Currently diabetes care accounts for $2-7 \%$ of the total national health care budgets in Western countries, amounting to $\$ 132$ billion in the United States in 2002 (ADA 2003). These data underline the importance of understanding the cellular mechanisms of the causes and complications of type 2 diabetes mellitus in order to offer better targeted and more effective treatment or even prevention of the disease.

Over the last decades, we have learned a lot from in vitro experiments in isolated tissues and cell cultures, but especially from in vivo studies in mouse models of modified insulin secretion or action (Nandi et al. 2004). Nevertheless, the phenotypes resulting from the various tissue-specific knockout or overexpression mouse models of diabetes or metabolic diseases do not generally resemble the phenotypes of corresponding diseases in humans. In addition to species differences and technical limitations of metabolic studies in small animals,

Clinical Diabetes Research: Methods and Techniques Edited by Michael Roden (C) 2007 John Wiley \& Sons, Ltd ISBN 978-0-470-01728-9 
this observation can likely be explained by gene-environment interactions influencing the human phenotypes of metabolic disorders. This makes detailed studies in humans under in vivo conditions mandatory.

Starting from simple endocrine and metabolic stimulation or suppression tests such as the insulin and glucagon administration or glucose tolerance tests, a series of more sophisticated tests has been developed over the last three decades. This development is mirrored by the near-exponential rise in original papers and reviews on the topics 'diabetes' and 'metabolic diseases' in peer-reviewed journals since 1970 (Figure 1.1). Among those publications, some key methodological papers speeded up the development of clinical metabolic research. These key papers include the description and validation of standardised insulin sensitivity and secretion tests such as the glucose clamp (Tobin et al. 1979) and minimal modeling of glucose and insulin concentrations during the intravenous glucose tolerance test (Bergman et al. 1981). Later on, tissue-specific metabolism became accessible by applying in vivo multinuclear magnetic resonance spectroscopy (MRS) (Shulman et al. 1990; Krssak et al. 1999) or positron emission tomography (PET) (Nuutila et al. 1993). Novel applications of stable isotopes as labels of molecules, e.g. ${ }^{2} \mathrm{H}_{2} \mathrm{O}$, later allowed quantification of complex metabolic fluxes such as rates of gluconeogenesis from different sources and glycogenolysis from one single blood sample (Landau et al. 1995) (NOTE: I would like to express my grief for my long-term mentor and friend, Professor Landau, an outstanding researcher and scientist in the field of metabolism, who passed away during the printing of this book). Combining the different techniques, e.g. MRS and ${ }^{2} \mathrm{H}_{2} \mathrm{O}$ (Kunert et al. 2003), further stimulated research on human metabolism and detailed metabolic phenotyping of various populations is now widely used.

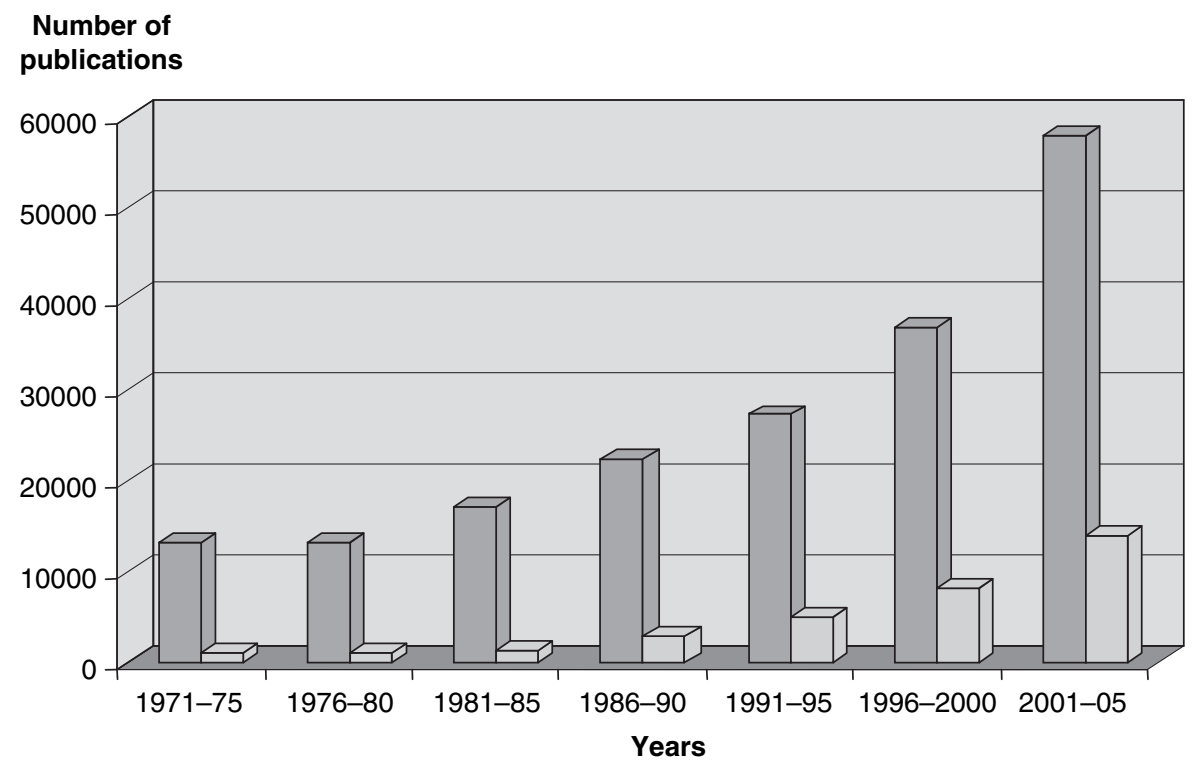

Figure 1.1 Number of original papers (dark columns) and reviews (light columns) in five-year intervals from 1970 to 2005 based on MEDLINE searching for the terms 'diabetes' or 'metabolic diseases'. 
Despite the rising interest in clinical research, many basic questions regarding metabolism in humans are unanswered or have not been addressed in sufficient detail. A major issue is the role of aging in intermediary metabolism. which was studied in detail in vivo in humans only recently. Petersen et al. (2004) assessed glucose fluxes and ectopic lipid deposition as well as mitochondrial oxidation and phosphorylation under in vivo conditions and found $\sim 40 \%$ lower flux rates through the tricarboxylic acid cycle and adenosinetris-phosphate synthesis, possibly explaining the reduced insulin sensitivity and elevated ectopic lipid content in elderly humans. Nevertheless, it remains unclear whether aging is generally associated with impaired insulin sensitivity; specific genetic or even acquired abnormalities could be responsible for reduced mitochondrial function not only during aging but also in other metabolic disorders (Stark \& Roden 2007). Likewise, sex and ethnicity can variably affect metabolic characteristics including body fat and its distribution, lipid metabolism and insulin action, which further complicates interpretation of clinical metabolic studies (Woods et al. 2003; Carulli et al. 2005).

These aspects of human metabolism culminate in the recent discussions on definitions of metabolic disorders summarised by the term '(dys)metabolic syndrome' or 'syndrome $\mathrm{X}$ ', which was introduced by Reaven about 20 years ago (Reaven 1988) and increasingly studied over the next decades (Figure 1.2). The World Health Organisation (WHO), the European Group for Insulin Resistance (EGIR), the Adult Treatment Panel (ATP III) and the International Diabetes Foundation (IDF) re-defined the metabolic syndrome, and more definitions are coming up due to different combinations and cut-off points of continuous variables, such as fasting plasma glucose, triglycerides or variable indices of body fat content (Table 1.1). The current discussion focuses on the relative importance of the compounds of the metabolic syndrome and the issue of whether it is a syndrome at all (Kahn et al. 2005). This controversy mostly results from different interpretations and understandings of this term, which can be used 1) to explain a series of factors by one underlying causal factor, be it insulin

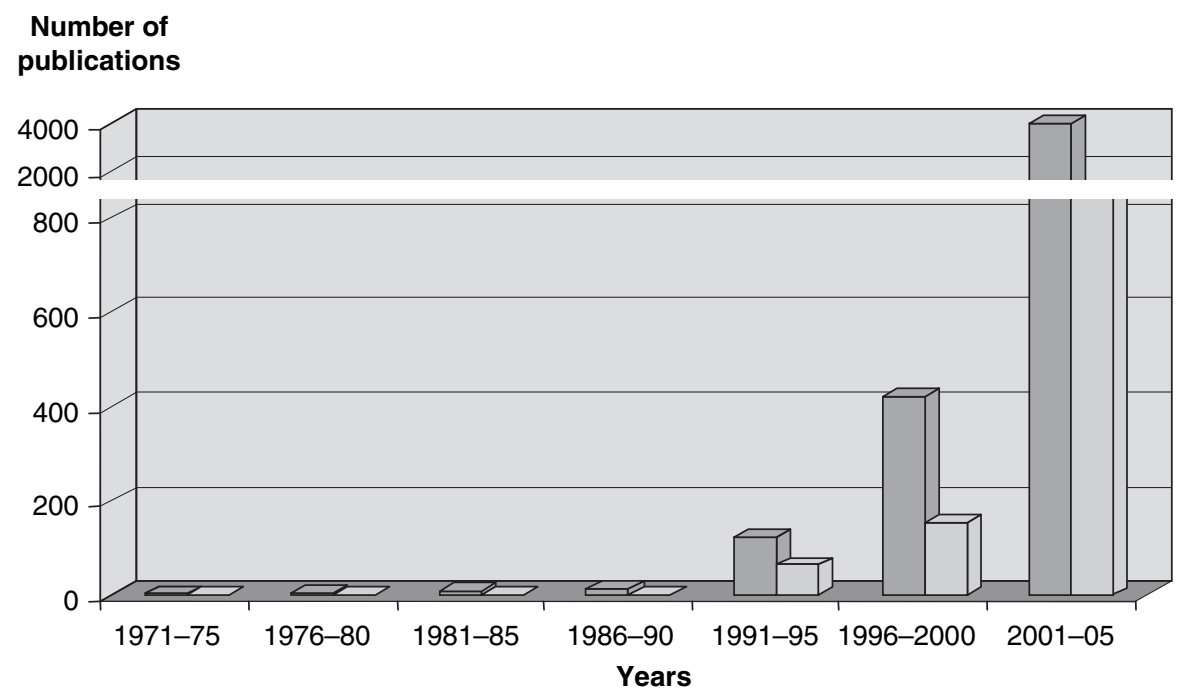

Figure 1.2 Number of original papers (dark columns) and reviews (light columns) in five-year intervals from 1970 to 2005 based on MEDLINE searching for the term 'metabolic syndrome'. 
Table 1.1 Definitions of the metabolic syndrome by the World Health Organisation (WHO), the European Group for Insulin resistance (EGIR), the Adult Treatment Panel (ATP III) and the International Diabetes Foundation (IDF). Key: DM - Diabetes mellitus; IGT - impaired glucose tolerance; IFG impaired fasting glucose

\begin{tabular}{|c|c|c|c|}
\hline WHO (1999) & EGIR (1999) & ATPIII (2001) & IDF (2005) \\
\hline $\begin{array}{l}\text { Main criteria } \\
\text { Insulin resistance } \\
\text { OR } \\
\text { DM / IGT / IFG }\end{array}$ & $\begin{array}{l}\text { Main criterion } \\
\text { Insulin resistance }\end{array}$ & & $\begin{array}{l}\text { Main criterion } \\
\text { Abdominal obesity }\end{array}$ \\
\hline $\begin{array}{l}\text { Other components } \\
\text { Hypertension } \\
\quad \geq 140 / 90 \mathrm{mmHg} \\
\text { Dyslipidaemia } \\
\text { Central obesity } \\
\text { Microalbuminura } \\
\text { (two or more) }\end{array}$ & $\begin{array}{l}\text { Other components } \\
\text { Hyperglycaemia } \\
\text { Hypertension } \\
\geq 140 / 90 \mathrm{mmHg} \\
\text { Dyslipidaemia } \\
\text { Central obesity } \\
\text { (two or more) }\end{array}$ & $\begin{array}{l}\text { Abdominal obesity } \\
\text { High triglycerides } \\
\text { Low HDL-C } \\
\text { Hypertension } \\
\quad \geq 130 / 85 \\
\text { mmHg High } \\
\text { fasting } \\
\text { glucose/DM } \\
\text { (two or more) }\end{array}$ & $\begin{array}{l}P L U S \\
\text { Hyper-triglyceridaemia } \\
\text { Low HDL-C } \\
\text { Hypertension } \\
\quad \geq 130 / 85 \mathrm{mmHg} \text { High } \\
\text { fasting } \\
\quad \text { glucose/DM } \\
\text { (two or more) }\end{array}$ \\
\hline
\end{tabular}

resistance or obesity; 2) to provide an easy cardiovascular risk cluster in addition to the known traditional risk makers such as cigarette smoking or LDL-cholesterol; or 3) to create a novel clinical syndrome or disease requiring specific treatment. We are currently lacking detailed knowledge of the interaction between numerous polygenic and environmental mediators, variation between populations and ethnic groups and time-dependent changes in these continuous variables. Above all, the physiological basis for the several metabolic disorders remains largely unknown at present.

In addition to its relevance for understanding human pathophysiology, clinical metabolic research is becoming important as a tool in clinical trials on non-pharmacological treatment and even more on drug treatment for today's major epidemiological threats. Of note, searching the MEDLINE detects 580 clinical trials in the 1970s, 1,464 in the 1980s, 5,236 in the 1990s - and already 7,568 between 2000 and 2006 .

The sections of this book cover the relevant aspects of current clinical research in humans and are designed to address the researcher's need for theoretical and practical knowledge in this field.

\section{References}

Abate N, Chandalia M (2003) The impact of ethnicity on type 2 diabetes J Diabetes Complications 17, 39-58

American Diabetes Association (ADA) (2003) Economic Costs of Diabetes in the US in 2002 Diabetes Care 26, 917-32

Bergman RN, Phillips LS, Cobelli C (1981) Physiologic evaluation of factors controlling glucose tolerance in man: measurement of insulin sensitivity and beta-cell glucose sensitivity from the response to intravenous glucose J Clin Invest 68, 1456-67

Carulli L, Rondinella S, Lombardini S, Canedi I, Loria P, Carulli N (2005) Review article: diabetes, genetics and ethnicity Aliment Pharmacol Ther 22, Suppl 2, 16-9 
DeFronzo RA, Tobin JD, Andres R (1979) Glucose clamp technique: a method for quantifying insulin secretion and resistance Am J Physiol 237, E214-23

Kahn R, Buse J, Ferrannini E, Stern M (2005) The metabolic syndrome: time for a critical appraisal. Joint statement from the American Diabetes Association and the European Association for the Study of Diabetes Diabetologia 48, 1684-99

King H, Aubert RE, Herman WH (1998) Global burden of diabetes, 1995-2025: prevalence, numerical estimates, and projections Diabetes Care 21, 1414-31

Kopelman PG (2000) Obesity as a medical problem Nature 404, 635-43

Krssak M, Falk Petersen K, Dresner A, DiPietro L, Vogel SM, Rothman DL et al. (1999) Intramyocellular lipid concentrations are correlated with insulin sensitivity in humans: a 1H NMR spectroscopy study Diabetologia 42,113-16, erratum on p. 386 and on p. 1269

Kunert O, Stingl H, Rosian E, Krssak M, Bernroider E, Seebacher W et al. (2003) Intramyocellular lipid concentrations are correlated with insulin sensitivity in humans: a 1H NMR spectroscopy study Diabetes 52, 2475-82

Landau BR, Wahren J, Chandramouli V, Schumann WC, Ekberg K, Kalhan SC (1995) Use of 2H2O for estimating rates of gluconeogenesis: application to the fasted state $J$ Clin Invest 95, 172-8

Nandi A, Kitamura Y, Kahn CR, Accili D (2004) Mouse models of insulin resistance Physiol Rev 84, 623-47

Nuutila P, Knuuti J, Ruotsalainen U, Koivisto VA, Eronen E, Teras M et al. (1993) Insulin resistance is localized to skeletal but not heart muscle in type 1 diabetes Am J Physiol 264, E756-62

Petersen KF, Befroy D, Dufour S, Dziura J, Ariyan C, Rothman DL et al. (2003) Mitochondrial dysfunction in the elderly: possible role in insulin resistance Science 300, 1140-2

Reaven GM (1988) Banting lecture 1988: role of insulin resistance in human disease Diabetes 37, 1595-1601

Roglic G, Unwin N, Bennett PH, Mathers C, Tuomilehto J, Nag S et al. (2005) The burden of mortality attributable to diabetes: realistic estimates for the year 2000 Diabetes Care 28, 2130-5

Shulman GI, Rothman DL, Jue T, Stein P, DeFronzo RA, Shulman RG (1990) N Engl J Med 322, 223-8

Stark R, Roden M (2007) Mitochondrial function and endocrine diseases - ESCI Award 2006 Europ $J$ Clin Invest (in press)

Ulbrecht JS, Cavanagh PR, Caputo GM (2004) Foot problems in diabetes: an overview Clin Infect Dis 39, Suppl 2, 273-82

Williamson DF, Vinicor F, Bowman BA (2004) Primary prevention of type 2 diabetes mellitus by lifestyle intervention: implications for health policy Ann Intern Med 40, 951-7

Woods SC, Gotoh K, Clegg DJ (2003) Exp Biol Med 228, 1175-80

Zimmet P (2005) Am J Med 118, Suppl 2, 3S-8S 
